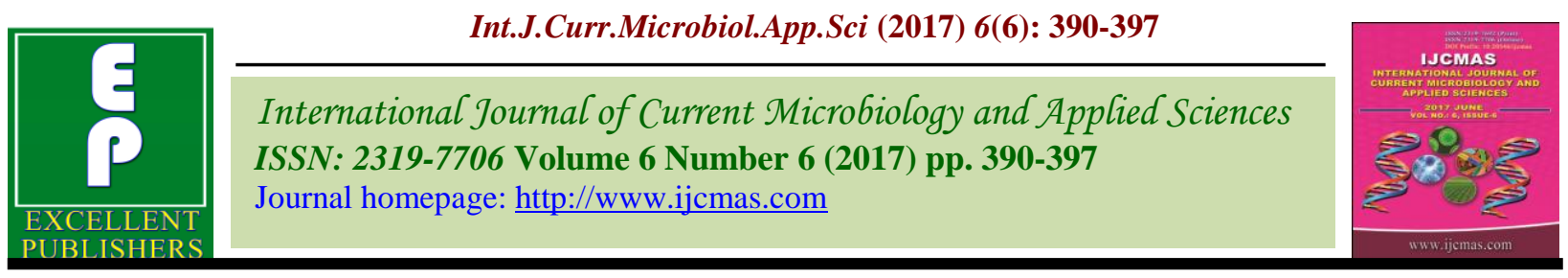

Original Research Article

https://doi.org/10.20546/ijcmas.2017.606.046

\title{
Organic Carbon Fraction and Vertical Distribution of Carbon under Integrated Nutrient Management System in Soybean-Chickpea Cropping Sequence in Vidarbha Region of Maharashtra, India
}

\author{
Pushpa Yadav ${ }^{1}$, Nitin Konde ${ }^{1}$ and Shiv Singh Meena ${ }^{2 *}$ \\ ${ }^{1}$ Department of Soil Science and Agricultural Chemistry, Dr. Panjabrao Deshmukh \\ Krishi Vidyapeeth, Akola, Maharashtra, India \\ ${ }^{2}$ Department of Soil Science, College of Agriculture, GBPUA \& T Pantnagar, \\ U. S. Nagar, Uttrakhand, India \\ *Corresponding author
}

\section{A B S T R A C T}

Keywords

Soil organic carbon fractions, Vertical distribution of organic and inorganic carbon, Soil Organic carbon stock, INM, Soybean-chickpea sequence.

Article Info

Accepted:

04 May 2017

Available Online:

10 June 2017
As an essential indicator of soil quality, soil organic carbon (SOC) and its fractions play an important role in many soil chemical, physical, and biological properties. The study was conducted during 2013-14 at research farm of Dr. P.D.K.V. Akola to find out the effect of integrated nutrient management on organic carbon fractions and vertical distribution of carbon under soybean-chickpea cropping sequence of a typic Haplustept of Vidarbha region of Maharashtra. Effect of varying doses of NPK, NPK + FYM, NPK + cotton stalk and NPK + phosphocompost on carbon fractions such as organic carbon, microbial biomass carbon, potassium oxidizable carbon, $\mathrm{CO}_{2}$ evolution and organic carbon stock was studied at 4th cycle of soybean-chickpea cropping sequence. Results revealed that application of FYM, phosphocompost and cotton stalk significantly increased the organic carbon, microbial biomass carbon, and $\left.\mathrm{KMnO}_{4}\right\urcorner$ oxidizable carbon and $\mathrm{CO}_{2}$ evolution over sole use of chemical fertilizers and control. However, maximum amount of soil organic carbon, microbial biomass carbon, $\mathrm{KMnO}_{4} \neg$ oxidizable carbon and $\mathrm{CO}_{2}$ evolution was found in $100 \% \mathrm{NPK}+5 \mathrm{t} \mathrm{FYM} \mathrm{ha}^{-1}$ treatment as compared to sole use of chemical fertilizers. Integrated use of FYM with chemical fertilizers or use of FYM alone exerted significant effect on soil organic carbon fraction.

\section{Introduction}

Soil organic carbon (SOC) plays an important role in soil fertility and productivity. Soil organic carbon can be used for assessing soil quality; it indicates the level of productivity of a given soil. Large amounts of SOC enhance water retention, prevent leaching of soluble nutrients, serve as source of sink for nutrients and maintain soil fertility (Bationo et al., 2009). SOC is one of the most important constituents of the soil due to its capacity to affect plant growth as both a source of energy and a trigger for nutrient availability through mineralization. SOC fractions in the active pool are the main source of energy and nutrients for soil microorganisms. Agricultural Practices such as addition of organic manures or residues, green manuring, FYM and intercropping with pulses etc. improves the content of soil organic carbon while recommended dose of NPK fertilizers alone does not sustain productivity under continuous intensive 
cropping system (Yaduwanshi, 2003). However, the combined application of organic manure and chemical fertilizers has been shown to improve SOC in comparison to addition of inorganic fertilizer alone (Mandal et al., 2003). Total organic carbon content is generally low under conventional cultivation and higher under NPK+ FYM amended soils. Crop production, nutrient uptake, physicochemical properties and microbiological properties of soil can be potentially improved by chemical fertilizers along with FYM (Ramesh et al., 2009). Manures application affects microbial biomass and carbon mineralization as compared to inorganic fertilization or control. The distribution of SOC with in different pools is an important consideration for understanding its dynamics and diverse role in ecosystems. Therefore, present study was carried out to study the effect of different options of nutrient management on active pools of SOC under soybean - chickpea cropping sequence of Typic Haplustepts.

\section{Highlights}

Effect of organic and inorganic fertilizers on organic carbon fraction

Vertical distribution of organic and inorganic carbon of experimental soil.

\section{Materials and Methods}

The study was carried out during the rainy season (kharif) of 2013-14 in a ongoing experiment of soybean-chickpea cropping system which was started in 2010-11 at the experimental farm of Dr. P.D.K.V. Akola. The climate of the experimental site is semiarid with hot and dry summers, maximum temperature goes up to $43.9^{\circ} \mathrm{C}$ during summers and as low $22^{\circ} \mathrm{C}$ during winters. The experimental soil was typic Haplusterts of $\mathrm{pH}$ 8.0 having $4.8 \mathrm{~g} \mathrm{~kg}^{-1}$ soil organic carbon and
$158 \mathrm{~kg} \mathrm{ha}^{-1}$ available $\mathrm{N}$ and 9.5 and $320 \mathrm{~kg}$ $\mathrm{ha}^{-1}$ available $\mathrm{P}$ and $\mathrm{K}$ respectively.

The experiment was laid out in randomized block design with 8 treatments and 3 replications. The 8 treatments were: T1(control), T2 (100\% RDF), T3 (100\% RDF+FYM@5t/ha), T4 (100\%RDF+FYM @5t/ha), T5 (50\%RDF and remaining $\mathrm{P}$ through phosphocompost), T6 (50\% RDF and remaining $\mathrm{P}$ through phosphocompost), $\mathrm{T} 7$ (75\% RDF and remaining $\mathrm{P}$ through phosphocompost) and T8 (100\% RDF through FYM and remaining $P$ through phosphocompost) in kharif for soybean and T1 (control), T2 (100\% RDF), T3 (75\% RDF), T4 (75\% RDF), T5 (75\% RDF +in situ soybean straw), T6 (100\% RDF +in situ soybean straw), $\mathrm{T} 7(50 \% \mathrm{RDF}+50 \% \mathrm{P}$ through phosphocompost) and T8 (In situ soybean straw + remaining $\mathrm{N}$ and $\mathrm{P}$ through phosphocompost) in rabi season for chickpea. The present study was carried out with soybean in kharif only. The gross and net plot sizes were $6.3 \times 7.7 \mathrm{~m} 2$ and $5.4 \times 7.7 \mathrm{~m} 2$ respectively. The nitrogen, phosphorous and potassium nutrients were applied through fertilizers viz. urea, single supper phosphate and murate of potash at time of sowing of soybean as perrecommended dose of NPK for soybean i.e. 100 per cent was 30:75:30 NPK $\mathrm{kgha}^{-1}$. Manual weeding was done as a part of intercultural operation as and when needed.

\section{Soil sampling and analysis}

Soil samples were collected after the harvest of soybean from each plot. The samples were air dried and processed to pass through $2 \mathrm{~mm}$ sieve. The sieved sample $(<2 \mathrm{~mm}$ size $)$ was used for determining organic carbon and available nutrients in whole soil. Organic carbon content was determined by Walkely and Black method, Alkaline $\mathrm{KMnO}_{4}$ oxidizable labilecarbon in soil sample was analysed as per procedure outlined by Blair $e t$ al., (1995) and microbial biomass carbon by 
the incubation and fumigation technique of Jenkinson and Powlson (1976). $\mathrm{CO}_{2}$ evolution was determined by alkali trap method as described by Anderson (1982), the inorganic carbon was determined by calcium carbonate content in soil by rapid titration(Acid neutralization) method described by Jackson (1973) while soil carbon stock was determined by multiplying soil organic carbon content with bulk density and soil depth (Batjes, 1996).

\section{Statistical test}

The data of different parameters were evaluated statistically appropriate to the design using F-test at 5\% level of significance as described by Panse and Sukhatme (1971).

\section{Results and Discussion}

\section{Organic carbon}

Long-term fertilizer experiments in different agro-eco regions of India involving a number of cropping systems and soil types indicated a decline in SOC as a result of continuous application of fertilizer alone. The organic matter added to soil is subjected to microbial decomposition and intensity of decomposition is a function of soil moisture, temperature and kind of organic input. Many studies have indicated a strong positive relationship between the amount of carbon incorporated into soil either in the form of crop residues or from external sources such as manures (Kundu et al., 2001). Organic carbon in soil after harvest of soybean crop ranged between $4.61 \mathrm{~g} \mathrm{~kg}^{-1}$ to $6.58 \mathrm{~g} \mathrm{~kg}^{-1}$ for $0-15 \mathrm{~cm}$ depth. The highest content of organic carbon was observed with the application of $100 \%$ RDF+FYM (T3 and T4) over control (T1). Significantly higher content of organic carbon was observed where plant residue, FYM, Phosphocompost and cotton stalk was applied. Proportionately higher carbon content in FYM added plots might be due to higher carbon input, slower break down or constant mineralization of organic residues. The organic carbon content of soil increased slightly due to cultivation of leguminous crop $(0.41 \%)$ as compared to soil under cereal $(0.38 \%)$ and fallow $(0.36 \%)$ (Sharma et al., 1986). The similar findings are also reported by Singh et al., (2004).

\section{$\mathrm{KMnO}_{4}$ oxidizable carbon}

Labile pool of carbon is the fraction of SOC that has the most rapid turnover rates and therefore, its oxidation drives the flux of carbon pool which is readily decomposable, easily oxidisable and susceptible to microbial attack and is sensitive to management induced changes in soil organic carbon. This pool is very important as it fuels the soil food web and greatly influences the nutrient cycling for maintaining the quality of soil and its productivity. The potassium permanganate oxidisable labile organic carbon was significantly influenced by the different treatments. Significantly higher amount of potassium permanganate oxidisable carbon was observed in the treatments where organic and inorganic were used in combination as compared to control and 100\% RDF through chemical fertilizers. The average $\mathrm{KMnO}_{4}-\mathrm{C}$ due to application of only chemical fertilizers (T2) was $337.88 \mathrm{mg} \mathrm{kg}^{-1}$ which was increased to $405.56 \mathrm{mg} \mathrm{kg}^{-1}$ with use of organics with chemical fertilizers (T4). The significantly highest $\mathrm{KMnO}_{4}-\mathrm{C}\left(477.65 \mathrm{mg} \mathrm{kg}{ }^{-1}\right)$ was recorded with sole use of organic fertilizers (T8). The lowest value $\left(315.77 \mathrm{mg} \mathrm{kg}^{-1}\right)$ of $\mathrm{KMnO}_{4}-\mathrm{C}$ was found in control (T1). The significant variations observed in the values of $\mathrm{KMnO}_{4}-\mathrm{C}$ due to different treatments reveal the sensitiveness of this labile carbon fraction to management options followed. This suggests importance of integration of organics with chemical fertilizers for enhancing soil quality attributes like labile 
carbon which is readily decomposed by microorganisms in soil.

\section{Soil microbial biomass carbon}

The soil microbial biomass carbon acts as the transformation agent of the organic matter in the soil. As such the biomass serves source and sink for the carbon and nitrogen as contained in soil organic matter. It plays central role in majority of biological activities in the soil. The results specified that application of $100 \%$ RDF + FYM@ $@$ tha $^{-1}$ in treatment $\mathrm{T} 4$ recorded significantly highest microbial biomass carbon (246.18 $\mu \mathrm{g} \mathrm{g}^{-1}$ ) followed by treatment T3 $\left(232.11 \mu \mathrm{g} \mathrm{g}^{-1}\right)$ with application of $100 \%$ RD + FYM @ $5 \mathrm{t} \mathrm{ha}^{-1}$. Treatment T8, where $100 \%$ RDN was given through FYM and remaining phosphorous was compensated through Phosphocompost showed a higher value of soil microbial biomass carbon $244.57 \mu \mathrm{g} \mathrm{g}^{-1}$ which was significantly higher than treatment $\mathrm{T} 7$ $\left(209.18 \mu \mathrm{g} \mathrm{g}^{-1}\right)$ where $50 \% \mathrm{RD}+50 \% \mathrm{P}$ through phosphocompost was applied. However, treatment T5 $\left(201.81 \mu \mathrm{g} \mathrm{g}^{-1}\right)$, T6 (204.79 $\left.\mu \mathrm{g} \mathrm{g}^{-1}\right)$ and $\mathrm{T} 7\left(209.18 \mu \mathrm{g} \mathrm{g}^{-1}\right)$ were found at par with each other.

The addition of organics i.e. FYM in combination with chemical fertilizers resulted into almost doubled the biomass over the control. Similarly, sole use of organics also significantly increased the soil microbial biomass as compared to RDF alone. The increase in soil microbial biomass carbon under organic treatments might be due to additional supply of mineralizable and readily hydrolyzable carbon through organic sources which, resulted in higher microbial activity and in return higher microbial biomass carbon. Bhatt et al., (2015) reported that soil microbial biomass carbon was largest with the integrated use of FYM and 100\% RDF, followed by in chemical fertilizer treated plot and smallest in the control.

\section{$\mathrm{CO}_{2}$ evolution}

Soil respiration provides evaluation of soil biological activity and extent of organic matter decomposition. Profound influence of integrated nutrient management treatments comprising of FYM, phosphocompost and cotton stalk with chemical fertilizers were found on soil respiration over only chemical fertilizer treatments. Highest $\mathrm{CO} 2$ evolution was observed under $100 \%$ RDF + FYM 5 t $\mathrm{ha}^{-1}$ (T4 and T3). Application of $100 \% \mathrm{RDF}$ through FYM and phosphocompost (T8) also recorded increased rate of $\mathrm{CO}_{2}$ evolution over the control. Application of organics stimulates and increases the living microorganisms in the soil involved in biochemical activity of importance to soil fertility and plant nutrition. Substantial increase in microbial biomass due to straw incorporation was reported by Powlson et al., (1987) and Bird et al., (2001). Thus the increased microbial biomass could have resulted in increased soil respiration rate.

\section{Vertical distribution of carbon}

The organic carbon in the soil varied from 4.61 to $6.58 \mathrm{~g} \mathrm{~kg}^{-1}$ in $0-15 \mathrm{~cm}, 3.37$ to $4.43 \mathrm{~g}$ $\mathrm{kg}^{-1}$ in $15-30 \mathrm{~cm}$ and 2.47 to $3.44 \mathrm{~g} \mathrm{~kg}^{-1}$ in $30-$ $45 \mathrm{~cm}$ depth after soybean crop.

The highest organic carbon was observed with the application of $100 \%$ RDF + FYM (T3 and T4) over control (T1) at all the three depth. Significantly superior content of organic carbon was noted where plant residue, FYM, Phosphocompost and cotton stalk was applied. Proportionately higher carbon content or carbon sequestration in the soil was recorded in FYM added plots which might be due to slower breakdown or constant mineralization of added organic residue. The similar findings were noted by Singh et al., (2004). 
Table.1 Effect of integrated plant nutrient system on organic carbon fraction in soil under soybean crop

\begin{tabular}{|c|c|c|c|c|c|}
\hline \multicolumn{2}{|c|}{ Treatments } & \multirow{2}{*}{$\begin{array}{c}\begin{array}{c}\text { Soil organic } \\
\text { carbon } \\
\left(\mathbf{g k g}^{-1}\right)\end{array} \\
4.61\end{array}$} & \multirow{2}{*}{$\begin{array}{c}\begin{array}{c}\mathrm{KMnO}_{4} \\
\text { oxidizable } \\
\text { carbon (mg } \\
\left.\mathbf{k g}^{-1}\right)\end{array} \\
315.77\end{array}$} & \multirow{2}{*}{$\begin{array}{c}\begin{array}{c}\text { SMBC } \\
\left(\boldsymbol{\mu g g}^{-1} \text { soil }\right)\end{array} \\
149.51\end{array}$} & \multirow{2}{*}{$\begin{array}{c}\mathrm{CO}_{2} \text { Evolution } \\
\text { (mg 100 } \text { g }^{-1} \text { soil) }\end{array}$} \\
\hline $\mathrm{T}_{1}$ & Control & & & & \\
\hline $\mathrm{T}_{2}$ & $100 \% \mathrm{RDF}$ & 6.01 & 337.88 & 190.51 & 33.16 \\
\hline $\mathrm{T}_{3}$ & $100 \% \mathrm{RDF}+\mathrm{FYM} 5 \mathrm{t} \mathrm{ha}^{-1}$ & 6.53 & 391.55 & 232.11 & 37.40 \\
\hline $\mathrm{T}_{4}$ & $100 \% \mathrm{RDF}+\mathrm{FYM} 5 \mathrm{tha}^{-1}$ & 6.58 & 405.56 & 246.18 & 39.23 \\
\hline $\mathrm{T}_{5}$ & $50 \% \mathrm{RDF}+50 \% \mathrm{P}$ through $\mathrm{PC}$ & 6.27 & 359.54 & 201.81 & 36.56 \\
\hline $\mathrm{T}_{6}$ & $50 \% \mathrm{RDF}+50 \% \mathrm{P}$ through PC & 6.37 & 365.21 & 204.79 & 36.52 \\
\hline $\mathrm{T}_{7}$ & $\begin{array}{l}75 \% \mathrm{RDF}+25 \% \mathrm{~N} \text { through } \\
\text { cotton stalk }\end{array}$ & 6.27 & 337.11 & 209.18 & 34.16 \\
\hline $\mathrm{T}_{8}$ & $\begin{array}{l}100 \% \text { RDF through FYM }+ \\
\text { remaining P through PC }\end{array}$ & 6.37 & 477.65 & 244.57 & 40.60 \\
\hline & $\mathrm{SE}(\mathrm{m} \pm)$ & 0.22 & 9.20 & 2.35 & 1.10 \\
\hline & $\mathrm{CD}$ at $5 \%$ & 0.68 & 26.76 & 6.843 & 3.197 \\
\hline & Initial & 4.80 & 316.23 & 149.51 & 23.22 \\
\hline
\end{tabular}

Table.2 Effect of integrated plant nutrient system on vertical distribution of organic and inorganic carbon and soil organic carbon stock under soybean crop

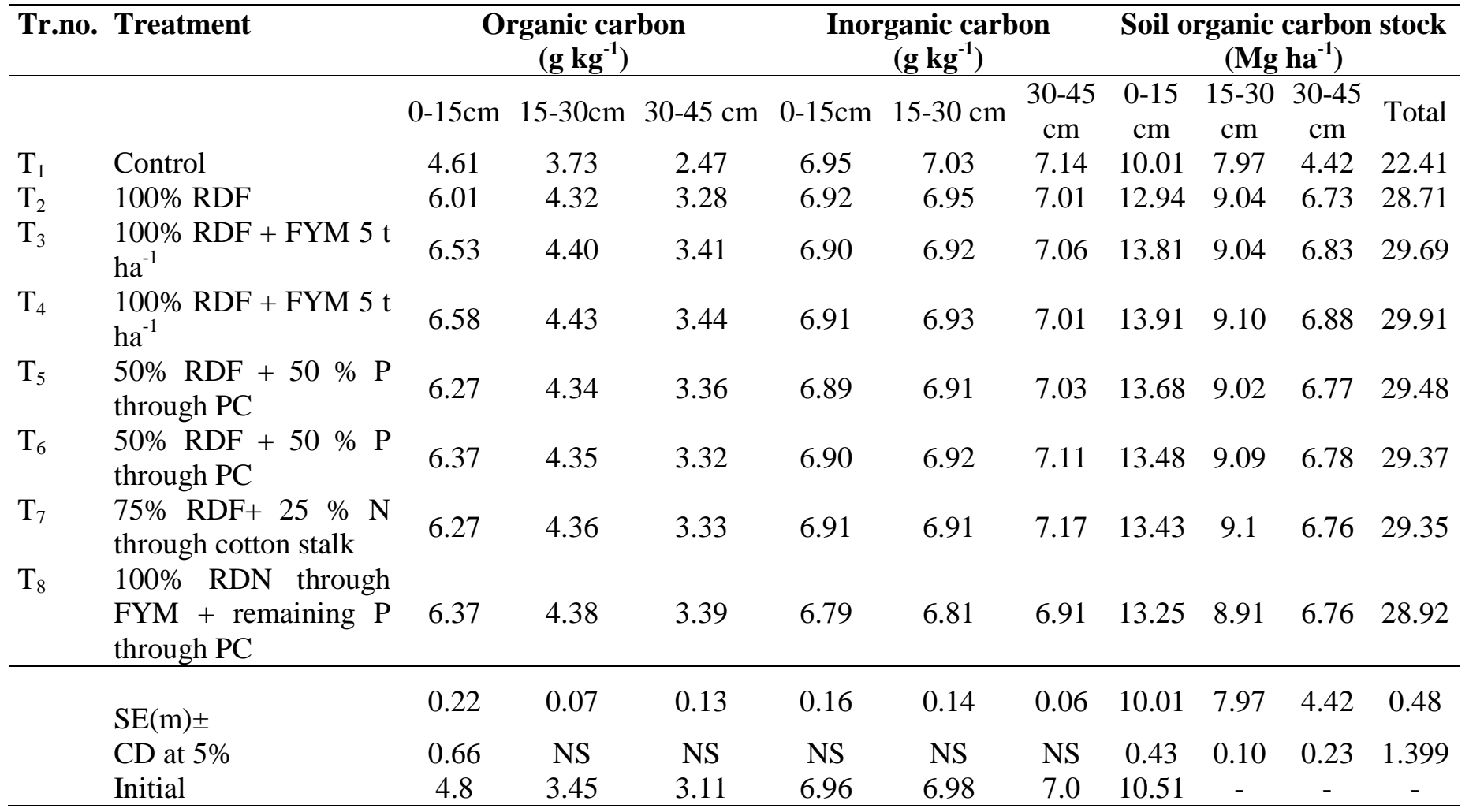


The initial value of organic carbon before start (2010-11) of the experiment was $4.8 \mathrm{~g}$ $\mathrm{kg}^{-1}$ which was enormously increased to 6.58 $\mathrm{g} \mathrm{kg}^{-1}$ under treatment $\mathrm{T} 4$ suggesting almost build-up of medium level of organic carbon content. It was also observed that, the organic carbon was stabilized after continuous manuring and fertilization. This can be attributed to oxidation of organic matter in soil owing to prevailing high temperature in semi-arid climatic areas. However, the conjoint use of chemical fertilizers with organics like FYM, phosphocompost and cotton stalk were found beneficial for maintaining organic carbon content compared to the use of only chemical fertilizers.

An application of FYM @ $5 \mathrm{t} \mathrm{ha}^{-1}$ along with $100 \%$ RDF to soybean in kharif and $100 \%$ and $75 \%$ RDF to chickpea in rabi were having comparatively more organic carbon (6.58 and $6.53 \mathrm{~g} \mathrm{~kg}^{-1}$ ) followed by $100 \% \mathrm{RDF}$ through FYM + remaining $\mathrm{P}$ through Phosphocompost (T8) and in situ soybean straw + Remaining N and $\mathrm{P}$ through phosphocompost in rabi. The lowest (4.61 $\mathrm{g} \mathrm{kg}^{-1}$ ) organic carbon content was noted in control (T1). The consistent increase in organic as well as inorganic carbon was also noticed under the treatments where crop residues and phosphocompost was used. While the studies conducted at various locations under long term fertilizer experiments revealed that the organic carbon was increased from 4.6 to $6.8 \mathrm{~g} \mathrm{~kg}^{-1}$ (Akola), 5.7 to $9.4 \mathrm{~g} \mathrm{~kg}^{-1}$ (Jabalpur) and 6.2 to $6.4 \mathrm{~g} \mathrm{~kg}^{-1}$ (Raipur). The slower development of organic carbon might be due to prevailing semi-arid climate. However, in Mollisol at Pantnagar, considerable increase in organic carbon from 14.8 to $16.1 \mathrm{~g} \mathrm{~kg}^{-1}$ was noted. It must be because of preservation of organic carbon under relatively cooler climate. In spite of regular application of organics in the Vertisols of semi-arid areas, the increase inorganic carbon was gradual. This has a great challenge for sustenance of soil quality
(Singh and Wanjari, 2007). A slight reduction in inorganic carbon was recorded in all the treatments over the initial soil test value. The inorganic carbon was in the range of 6.79 to $6.95 \mathrm{~g} \mathrm{~kg}^{-1}$ in $0-15 \mathrm{~cm}, 6.81$ to $7.03 \mathrm{~g} \mathrm{~kg}^{-1}$ in $15-30 \mathrm{~cm}$ and 6.91 t0 $7.17 \mathrm{~g} \mathrm{~kg}^{-1}$ in $30-45 \mathrm{~cm}$ depth respectively. While, it was $6.97 \mathrm{~g} \mathrm{~kg}^{-1}$ before start of the experiment. The content of inorganic carbon was somewhat more in control treatment. The decrease of inorganic carbon in organic treatments might be due to dissolution of carbonates by the organic acids released during the decomposition of organic materials which might have reacted with $\mathrm{CaCO}_{3}$ to release $\mathrm{CO}_{2}$ thereby reducing $\mathrm{CaCO}_{3}$ content of the soil. This process also helps in building up a higher $\mathrm{Ca}^{2+}$ ion concentration in soil. However, the changes at the end of study period were not identical with respect to treatments. It is further to note that the content of inorganic carbon was gradually increased with increase in depth. The higher amount of inorganic carbon (7.17 $\mathrm{g} \mathrm{kg}^{-1}$ ) was noticed at $30-45 \mathrm{~cm}$ depth as compared to surface layer. This could be due to arid prone climate during summer which led to formation of pedogenic $\mathrm{CaCO}_{3}$ that induce development of sub soil sodicity. The results are in conformity with the findings of Sahrawat et al., (2005) and Khambalkar et al., (2013).

\section{Organic carbon stock of the soil}

The size of total soil organic carbon stock involves two steps (Batjes, 1996). The first step involves calculation of organic carbon by multiplying organic carbon $\left(\mathrm{g} \mathrm{g}^{-1}\right)$ with bulk density $\left(\mathrm{Mg} \mathrm{m}^{-3}\right)$ and thickness of soil layer (cm). In second step SOC determined by the first step multiplied by the area. On the similar background the soil organic carbon stalk was computed and presented in table 2 . The total soil organic carbon stock was higher in treatments which were receiving integrated use of fertilizer against sole use of chemical 
fertilizers, absolute organics and control. The buildup in soil organic carbon stock with integrated nutrient management was due to the increased level of organic carbon in the soil. This might be because of direct application of FYM, phosphocompost and cotton stalk. Similarly, addition of higher biomass by soybean has also greater significance in enhancing the organic carbon stock of the soil. Soil organic carbon is mainly determined on the basis of bulk density and plough layer of the soil. The bulk density of the experimental site was nonsignificant during initial test value of the soil. The significant increase in soil organic stock in soil treated with either through chemical fertilizers or organic manures was obtained. Similar results were found by and Benbi et al., (2012) and Srinivasarao et al., (2012) (Tables 1 and 2).

In conclusion, application of organic fertilizers along with inorganic fertilizers in soybean- chickpea sequence has a major influence on soil organic carbon and various carbon pools. It was found that application of organic along with chemical fertilizers increased the level of soil organic carbon, soil microbial biomass carbon, $\mathrm{CO}_{2}$ evolution and potassium permanganate oxidizable carbon. The positive effect of integrated nutrient management system was also being seen on soil inorganic carbon and soil organic carbon stalk. All the sources of organics (FYM, Phosphocompost and cotton stalk) were found beneficial in improving soil organic carbon and microbial biomass carbon. It is indicative of the nutrient turn over at higher carbon expenses met through added organic carbon.

\section{References}

Anderson, J.P.E. 1982. Soil respiration.In 'Methods of soil analysis. Part 2: Chemical and microbiological properties'. Agronomy Monograph No.
9. (Ed. AL Page) pp. 831-871. (SSSAASA: Madison, WI)

Bationo, A., Kihara, J., Vanlauwe, B., Waswa, B., Kimetu, J. 2005. Soil Organic Carbon Dynamics, Functions and Management in West African AgroEcosystems. Science direct, 13-25.

Benbi.D.K, A.S.Toor., S. Kumar. 2012. Management of organic amendments in rice- wheat cropping system determines the pool where carbon is sequestered.Plant.Soil.360:145-162.

Bharadwaj, V.andOmanwar, P.K. 1994. Long term effects of continuous rotational cropping and fertilization on crop yields and soil properties. Ec, $\mathrm{pH}$, Organic matter and available nutrients on soil J.Indian. Soc. Soil. Sci. 42 (3): 387-392.

Bird, J.A., W.R. Horwath, A.J. Eagle and C.V. Kessel, 2001. Immobilisation of fertilizer nitrogen in rice: Effects of straw management practices. Soil Sci. Soc. Am. J. 65: 1143-1152.

Blair, G.J., Lofroy, R. D. B. and Lisle, L. 1995. Soil carbon fractions based on their degree of oxidation, and the development of a carbon management index for agriculture systems. Australian Journal of Agricultural Research 46, 1459-1466.

Jackson, M. L., 1973. Soil chemical analysis.Prenitice Hall of India, New Delhi.

Jenkinson, D.S. and J.N. Ladd. 1981. Microbial biomass in soil, measurement and turnover in:Soil Biochemistry,pp.415-471.

Khambalkar P.A., P.S. Tomar, S.K.Verm., 2013 Influence of integrated nutrient management on carbon sequestration and its relationship with productivity of pearlmillet (Pennisetum glaucum)mustard (Brassica juncea) cropping sequence. Indian J.of Agronomy 58 (4): 480-489. 
Kundu, S., M.Singh, J.K.Saha., A.Biswas., A.K.Tripathi and C.L.Acharya 2001. Relationship between $\mathrm{C}$ addition and storage in a Vertisol under soybeanwheat cropping syetem in sub- tropical central India.J.PlantNutr. Soil Sci.164, 483-486

Mandal, U.K., Singh, G., Victor, U.S., Sharma, K.L., 2003. Green manuring: its effect on soil properties and crop growth under rice-wheat cropping system. European journal of agronomy, 19, 225-237.

Nelson,D.W.,and Sommer,L.E.,1996.Total carbon, organic carbon and organic matter. In: Methods of soil analysis. Part 3.Chemical methods- SSSA Book series no. 5.

Panse, V.G. and P.V. Sukhatme, 1971.Statistical Methods for Agricultural Workers. ICAR, New Delhi.

Powlson, D.S., P.C. Brooks, B.T. Christensen, 1987.Measurement of soil microbial biomass provide an early indication of changes in total soil organic matter due to straw incorporation. Soil Biol. Biochem. 19: 159-164.

Ramesh, P., N. R. Panwar, A. B. Singh and S. Ramana. 2009. Production potential, nutrient uptake, soil fertility and economics of soybean-based cropping systems under organic, chemical and integrated nutrient management practices. Indian J. Agron. 54(3): 278283.
Sahrawat, K. L., T. Bhattacharyya, S. P. Wani, P. Chandran, S. K. Ray, D. K. Paland K. V. Padmaja. 2005. Long-term lowland rice and arable cropping effects on carbon and nitrogen status of some semi-arid tropical soils. Current Science, 89(12): 2159-2163.

Sharma, C.P., H.S. Gupta and P.D. Bajpai, 1986.Residual Effect of leguminous crop on some chemical and microbiological properties of soil. J. Indian Soc. Soil Sci. 346: 206-208.

Singh, Yadvvinder, Bijay Singh, J. K. Ladha, C. S. Khind, R. K. Gupta, O. P. Meelu and E.Pasuquin 2004.Long-Term Effects of Organic Inputs on Yield and Soil Fertility in the Rice- Wheat Rotation. Soil Sci. Soc. Am. J.68:845853.

Srinivasrao, C. K., P. R. Vittal and B. Vekenteswarlu, 2009. Carbon stock in different soil types under diverse rainfed production systems in tropical India. Communication in Soil and Plant Analysis, 40: 2338-2356.

Walkley,A.J.and Black, I.A.1934. An examination of the degtareff method for for determining soil organic matter and a proposed modification of the cromic acid titration method. Soil Sci.37:29-38.

Yaduwanshi, N.P.S., 2003. Substitution of inorganic fertilizer by organic manures and the effect on soil fertility in a rice wheat rotation on reclaimed soil in India. Journal of Agricultural science, 140,161-168.

\section{How to cite this article:}

Pushpa Yadav, Nitin Konde and Shiv Singh Meena. 2017. Organic Carbon Fraction and Vertical Distribution of Carbon under Integrated Nutrient Management System in SoybeanChickpea Cropping Sequence in Vidarbha Region of Maharashtra, India. Int.J.Curr.Microbiol.App.Sci. 6(6): 390-397. doi: https://doi.org/10.20546/ijcmas.2017.606.046 